\title{
Justice, Blindfolded: Law and Crime in the Celestina
}

\author{
Marlen Bidwell-Steiner
}

\begin{abstract}
La Celestina is a breakthrough in the development of Spanish narratives from educational purposes towards multi-layered literary worlds and thus crucial for the interaction between casuistry and imaginative literature. The plot's casualties are framed by soliloquies referring to legal and ethical questions. On a rhetorical level, law is present in the master trope of blind(folded) justice. Combining a close reading of these soliloquies with contemporaneous casuistical writings and an iconological search for evidences elucidates the intention of this contested masterpiece.
\end{abstract}

\section{Keywords}

Celestina - casuistry - justice - iconology - Cisneros - Nebrija

The Tragicomedia de Calisto y Melibea (around $1500 / 1507)^{1}$ is one of the most debated texts in Hispanic literary studies. Despite the persistent interest of experts from all over the world, La Celestina - as the text became known in Spanish literary memory shortly after its first editions - still remains an enigmatic work. One of its mysteries concerns authorship, and already comes to the fore in its preliminary texts. In "El autor a un su amigo" the writer gives us some information about the origins of the work: he allegedly composed it as a sort of leisure activity while preparing for his final exams in legal studies. Furthermore, he claims to have written it after having found the text of the first auto, whose possible authors (Juan de Mena and Rodrigo Cota) he discusses. In a rhetorical feint, he insists on not disclosing his own name. Yet, there is the ensuing acrostic in which Fernando de Rojas professes he at least finished ("acabó") the comedia of 16 autos. And to complicate the whole issue

1 The dating of 1507 refers to the oldest Spanish edition of the tragicomedia from Zaragoza. Yet already in 1506, there appeared a translation in Rome, and the afterword of the corrector Alonso de Proaza points to the year of 1500 . There is an ongoing debate about the archetype of the tragicomedia and its relationship to comedia with the oldest surviving versions from 1499, 1500 and 1501. A significant edition of the tragicomedia is Valencia 1514. For the question of authorship and editorial history of the text see Serés $361-401$. 
even more, we have the preface to the tragicomedia of 21 autos, which links its additional interpolations to debates with the author's friends over the semantics of the comedia:

Así que cuando diez personas se juntaren a oír esta comedia en quien quepa esta diferencia de condiciones, como suele acaecer, ¿quién negará que haya contienda en cosa que de tantas maneras se entienda? ROJAS 20

My essay takes the lead of Celestina's introductory voice at its word, since this paratext already refutes a clear-cut message of an alleged reprobatio amoris by means of an exemplum ex negativo. Although it is not possible to reconstruct such an early 16th-century "battle of words" over the significance of the plot, it might help to identify some competing voices that possibly inform its peripeties. To trace them, I would like to elaborate on the "diferencia de condiciones" and expose them to the professional battlefield of La Celestina's author namely, jurisprudence. In this field of utrumque ius, two different traditions of casuistry meet: legal students had to become versed in Roman law and in canon law. In medieval and early modern Spain, these two written corpora interacted and sometimes competed with feudal customary law:

La solución fue considerar el derecho romano como ius commune para las cosas temporales; el canónico como ius commune para las cosas espirituales; y el derecho local y consuetudinario como una suerte o clase de derecho especial [...].

JUSDADO RUIZ-CAPILLAS 333

In this essay I will identify frictions between these different legal systems. As the tragic events of La Celestina's plot lead to death, they tend towards the spiritual sphere and therefore will mainly be read against the backdrop of texts from the corpus of canon law. Subsequently, discrepancies between canonical and civil law will be elaborated. Such conceptual clashes become apparent in a passage of the Celestina that does not belong to the so-called "primitiva comedia" - the shorter first version of the text ${ }^{2}$ - but instead constitutes an

2 This labeling was coined by Marcel Bataillon (54-76) for the shorter - and allegedly - older version of the text; this opinion, however, has been quite contested ever since Charles Faulhaber discovered the Celestina de Palacio in 1990, a fragmented manuscript of the comedia, which contains elements closer to the tragicomedia (Faulhaber 1990, 1991). For discussions on the editorial fortune of the text see Serés $382-401$. 
interface for Celestina's transformation into a tragicomedia: the protagonist Calisto's soliloquy at the end of auto 14. In what we might call a stream of consciousness, Calisto reflects on the three casualties that have occurred so far: after providing him access to Melibea, the object of his desire, the procuress Celestina has been stabbed to death by his two servants, who have in turn been hanged immediately afterwards.

The following narratological analysis will show how a society in flux evinces not only changing norms but also sophisticated cultures of play - including, under the auspices of the new printing technology, literature. In this context, a close reading of Calisto's soliloquy helps to shed light on the author's playful interweaving of competing options of meaning. ${ }^{3}$

Interestingly, every case of death in the diegeses is framed by similar meditations. One is Melibea's confession to her father Pleberio after Calisto's accident, a fatal fall from the wall of their "garden of lust" in the penultimate auto. Another such meditation is Pleberio's famous lament over the vicissitudes of the fickle goddess Fortuna, when he is confronted with the suicide of his daughter at the very end of the text. Yet these two monologues also appear in the comedia, whereas Calisto's musings form the intersection of the additional five autos that change the text into a tragicomedia. Therefore, Calisto's soliloquy constitutes an important hinge of the plot's overall semantics, also impacting the meaning of Melibea's and Pleberio's monologues, as will be shown after a thorough analysis of Calisto's cogitations.

To begin with, I will confront the protagonists' reflections with two almost contemporaneous instructions for the inspection of guilt during confession, the Libro sinodal and the Confessional del Tostado. Calisto's monologue highlights the circumstances of the plot line and therefore (albeit obliquely) echoes casuistical speech. This becomes obvious when examined in relation to what later became labelled the Jesuit hexameter - a mnemonic already established in the Middle Ages, e.g., in Gonzalo de Alba's Libro sinodal of 1410: "Quis, quid, ubi,

3 Consolación Baranda set a similar track in confronting the passage with texts by Fernando de Roa, a famous jurist at the University of Salamanca at the time of Celestina's origin. It is a valuable resource, yet in examining Calisto's complaints as indicators of social reality, Baranda pursues an opposite - or perhaps complementary - objective to my narratologically oriented analysis. 
per quos, quotiens, cur, quomodo, quando: Quidlibet obseruet, anime medicamina dando" (Gonzalo de Alba 221).

Bishop Gonzalo de Alba directed his text "a los que cura tienen de animas" (Gonzalo de Alba 177). The fact that the text's purpose is not primarily pastoral but catechetical makes all the more apparent how meticulously the specific circumstances of each case (read: sin or lapse) are discussed in medieval confessionals (Soto Rábanos 441). An important catalyst for the genre was the fourth Council of Lateran (1215); from then on, the sacrament of penitence became crucial for pastoral care. With the printing of such texts in the vernacular at the turn of the 16th century, the Spanish populace became ever more proficient at examining their consciences, sometimes even complaining about the lack of sophistication on the part of their confessors (O'Banion 338).

Evidently, the Libro sinodal had a doctrinal purpose, and thus not only encompasses penance but all the other sacraments, the so-called artículos de la fe, the seven virtues, etc. It belongs to an authoritative scholastic tradition relying on the Corpus Iuris Canonici (Sánchez Herrero 1079). The Libro sinodal's salient character of orthodoxy contrasts with another influential text, the Confessional del Tostado, which notably challenges some Catholic practices (cf. Bechtel). It was written by Alfonso Fernández de Madrigal (ca. 1410-1455), nicknamed Tostado, who studied law at the University of Salamanca, where he later became rector of the Colegio Mayor de San Bartolomé and was famous for his erudition, as is evidenced by the compliment: "saber o haber escrito más que el Tostado” (Saquero Súarez-Somonte/González Rolán 87).

Without further specification, a "confisario" is also listed in the book inventory of Fernando de Rojas (Infantes 30). Of course, there is an ongoing debate on whether Rojas was the exclusive author of the tragi/comedia, and his acquaintance with Tostado's Confessional cannot be proved. Nevertheless, the Confessional is a significant text for understanding Calisto's casuistical argumentation, since in the (spatial and temporal) vicinity of the Celestina there are few other books which saw as many editions as Tostado's text. Moreover, one much-discussed source of the Celestina, the Tratado de cómo al hombre es necesario amar, is also attributed to Tostado (see Paolini; Cátedra 113-141). With his academic endeavors, Tostado initiated a flourishing humanism at the University of Salamanca.

Both texts, the Libro sinodal and Tostado's Confessional, help us to reconstruct contemporaneous moral debates as they informed imaginative literature in various ways. Concerning the act of penance, both texts adopt the common pattern of such manuals: after describing the ritual setting and necessary habitus of a penitent, they mainly debate the saligia - the "palabra mágica" (Soto 
Rábanos 417) or acronym for the seven capital sins, Superbia, Avaritia, Luxuria, Ira, Gula, Invidia, Acidia. Tostado goes without mentioning the term saligia and even changes the acronym's order into soberbia, lujuria, gula, envidia, ira, pereza (= acidia) and avaricia. Such a rearrangement is highly significant, since the formula was meant to become habitual, repeated over and over. His prioritizing of lust reflects a concern for sexual mores in 15th-century Spain, especially on the part of practicing and aspiring clerics. After elaborating on the circumstances in each of the sins, both authors follow with an explanation of the Ten Commandments, sometimes recapitulating major elements. Gonzalo de Alba proceeds slightly differently, offering a chapter exclusively on the circumstances of capital sins.

Indeed, these texts provide a comprehensive, meticulous inspection of individual mis/behavior for confessor and penitent. When every minor detail is divulged, the outer and inner - material and psychic - aspects of a penitent's vices help flesh out each unique "caso." This in turn can be understood as a narrativization or emplotment of the sacrament of penance. ${ }^{4}$ As such, these penitential texts underscore the individual's responsibility and thus foster the process of subjectivization: presumably, exhaustive pastoral monitoring over the liturgical year with at least one major confession enhanced the selfawareness of every community member. The whole process must have necessitated soliloquies to prepare for the act of penitential purification, since the instructions repeatedly stipulate a detailed oral description of the sin committed (Gonzalo de Alba 211).

Calisto's monologue reads like a preposterous version of such a preparation for penance. Considering this, what is he really pondering?

¡Oh mezquino yo, cuánto me es agradable de mi natural la solicitud y silencio y escuridad. No sé si lo causa que me vino a la memoria la traición que hice en me despartir de aquella señora que tanto amo hasta que más fuera de día, o el dolor de mi deshonra. ¡Ay, ay, que esto es; Esta herida es la que siento; agora que se ha resfriado, agora que está helada la sangre que ayer hervía, agora que veo la mengua de mi casa, la falta de mi servicio, la perdición de mi patrimonio, la infamia que a mi persona de

4 For a discussion of sacrament and confession in Spanish drama, see Kallendorf, in this volume. 
la muerte de mis criados se ha seguido! ¿Qué hice? ¿En qué me detuve? ¿Cómo me pude sofrir que no me mostré luego presente como hombre injuriado, vengador soberbio y acelerado de la manifiesta injusticia que me fue hecha? [...] ¿Qué haré? ¿Qué consejo tomaré?

ROJAS $277-278$

As Hilaire Kallendorf (64 sig.) points out, the final question (¿Qué consejo tomaré?) is a clear indication of casuistical speech. To begin with, Calisto's first words apparently designate an awakening from his amor hereos: he seems to be acknowledging his duty to act after the execution of his servants. He almost gives the impression he has been cured of what medical casuistry would have called his melancholic wound - what was burning the day before has now cooled off: "Esta herida es la que siento ahora, que se ha resfriado." If we follow Tostado's writing, the protagonist seems to be in the ideal mood for penitence, since he exhibits the need for emotional involvement: "se deue mucho entristecer por hauer fecho tales y tantos males" (Tostado $3 \mathrm{v}$ ).

Yet Calisto's contrition is only skin-deep, because his self-perception shifts from culprit to injured party, from "la infamia que tiene mi persona de la muerte" to "hombre injuriado, vengador, soberbio y acelerado de la manifiesta injusticia que me fue hecha." One could even argue that his initial regret already only aims at his reputation, because infamia rather means loss of honor than a personal lapse. Interestingly, in this passage the protagonist assumes soberbio to be a positive personal trait; in fact, his concern for honor - "el dolor de mi deshonra" - correlates with Tostado's initial explanation of the first mortal sin soberbia: "Acerca del pecado de la soberuia es de considerar que en muchas maneras pecamos: Primeramente en deseo de honrra" (Tostado 8 v). Thus, against the backdrop of the Confessional, Calisto's first sentences already read as an ironic distortion of the confessional situation.

As an expression for social shame, infamia points to other (possible) perpetrators. And indeed, Calisto suddenly refers to such a person:

¡Oh cruel juez, y qué mal pago me has dado del pan que de mi padre comiste! Yo pensaba que pudiera con tu favor matar mil hombres sin temor de castigo, jinicuo falsario, perseguidor de verdad, hombre de bajo suelo! Bien dirán de ti que te hizo alcalde mengua de hombres buenos. Miraras que tú y los que mataste en servir a mis pasados y a mí érades compañeros. Mas cuando el vil está rico, no tiene pariente ni amigo.

ROJAS 278-279 
On the surface, this passage confirms Calisto's overall flawed character as he tries to blame the judge for his own faults. Calisto refers to his feudal privilege and the judge's obligation to Calisto's family - resulting in his awkward verdict holding the judge guilty of having executed his symbolic brothers, for he and the criados all were serving the same noble family: "Miraras que tú y los que mataste en servir a mis pasados y a mí érades compañeros."

In displacing the subject of the crime, the quis, from the servants (or himself) to the judge, Calisto's monologue betrays a subtly casuistical reframing of the circumstances of the servants' execution. This can be read as a mockery of confessional guidelines, which very explicitly warn against blaming other people (Tostado 56v). Calisto plays the "cruel act" of the judge against the homicide committed by the two servants, and in so doing gives a striking misrepresentation of the quis and the quid:

Tú eres público delincuente, y mataste a los que son privados; y pues sabe que menor delito es el privado que el público, menor su utilidad, según las leyes de Atenas disponen, las cuales no son escritas con sangre, antes muestran que es menos yerro no condenar los malhechores que punir los inocentes. ¡Oh cuán peligroso es seguir justa causa delante injusto juez! Cuanto más este exceso de mis criados, que no carecía de culpa.

ROJAS $279-28$ o

According to Calisto, the judge as public authority committed a worse crime than the servants, since he punished - without a formal trial - their crime with execution i.e., blood, which in Calisto's perspective constitutes a violation of public law ("leyes de Atenas"). The use of privado as a noun once more emphasizes the point that these servants are not invested with legal capacity; consequently, the only possible juridical persona on their behalf would be Calisto himself. He further elaborates on the antithesis of public-private mingling quid with $u b i$, i.e., the location of the case: the crime was done in private ("y pues sabe que menor delito es el privado que el público"). Yolanda Iglesias is one of the few scholars who has linked such instances of death in the Celestina to contemporaneous juridical discourse, albeit without mentioning casuistry. She argues that medieval law considered intrusion into a private home as a more severe crime than public murder (Iglesias 63). Yet, Calisto's reflection is consonant with contemporaneous interpretations of Roman law, as the anonymous author of the Celestina Comentada proves (412) and it also is in accordance with the circumstantial norms elaborated in the Libro sinodal, where 
Gonzalo de Alba classifies crimes perpetrated in public as a greater offense, since they bear the danger of instigating imitators:

Item, si el pecado que cometio, si es publico o ascondido, ca mas peca el que peca publicamente que el que es ascondido, ca el que peca publicamente, con su mal enxienplo muchos escandalisa e corronpe.

GONZALO DE ALBA 221

Since Calisto's considerations draw on moralistic debates, it comes as no surprise that his accusation of the judge is interwoven with a reference to God: "Pues mira, si mal has hecho, que hay sindicado en el cielo y en la tierra: así que a Dios y al rey serás reo, y a mí capital enemigo" (Rojas 280). This doubling of the judge's guilt is interesting in that it insinuates a distinction between canon and civil law. Calisto's intricate argument that the judge is a wrongdoer before the king seems to refer to the patria potestas in Roman law, where household members (including servants) are alieni iuris and thus subordinated to the pater familias, who is the only one to enjoy personhood sui iuris (Benke 286). Taking a lead from our protagonist, we could even argue that the judge bears a quadruple guilt, since both servants were executed, although only one stabbed Celestina: “¿Qué pecó el uno por lo que hizo el otro, que por sólo ser su compañero los mataste a entrambos?" (Rojas 280).

Secular punitive measures do not distinguish between the actual perpetrator and the initiators of the crime - both are considered guilty: "hacientes y consintientes merecen igual pena," as Calisto concedes immediately afterwards. Our anonymous commentator mentions in this context the Siete Partidas VII, tit. I, l. 10 as one source of the argument (c.c. 419). However, there is a slight variance in moral views: although the mere intention of murder counts as a sin in itself, dirtying one's hands with the deed does make a difference. In moral debates, this raises the question of whether someone sinned actively or passively, and thus refers to the quomodo (cf. Gonzalo de Alba 222). And in light of another synodal norm, the two servants not only committed murder but also "asechanzas" ("traps", cf. Guiance), since they blindsided their victim and prevented her from obtaining spiritual help, as Celestina's last exclamation underscores: “¿Confesión!” (Rojas 261).

\section{$3 \quad$ Sophistic Argumentations}

Yet, after coming to his wits again - "Pero ¿qué digo? ¿Con quién hablo? ¿Estoy en mi seso? ¿Qué es esto, Calisto? [...] Torna en ti” (Rojas 280) - Calisto 
concludes that the judge might have had good arguments for executing both men. We now also learn that the prompt execution might be considered an act of mercy toward the perpetrators because they were already severely injured, and also because the evidence for their punishment was sufficient, seeing that they were caught in the act:

¿No ves que por ejecutar justicia no había de mirar amistad ni deudo ni crianza? ¿No miras que la ley tiene que ser igual a todos? [...] Considera que si aquí presente él estoviese, respondería que hacientes y consintientes merecen igual pena, aunque a entramos matase por lo que el uno pecó, y que si aceleró en su muerte, que era crimen notorio y no eran necesarias muchas pruebas, y que fueron tomados en el acto del matar, que ya estaba el uno muerto de la caída que dio.

ROJAS 280

Narratologically, this is quite a significant passage because at this point the soliloquy shifts focalization: whereas at the beginning Calisto addressed the other - his enemy, the judge - with "you," now his ostensible self-examination ("torna en ti") materializes on the level of discourse in contrast to the significance of the words. All of a sudden, he refers to himself with "you" and addresses the judge in the third person.

As we shall see, this strategy of self-othering is meant to reveal the protagonist's presumptuous self-aggrandizement. This plot device constitutes a rhetorical correlation to the satirical distortion of juridical discourse that then follows. Calisto recalls the legal imperative of hearing both parties with a comic twist: he denies the judge his role as arbiter and arrogates to himself the role of judging his own case. In this context, Calisto echoes an argument developed earlier in the comedia by none less than the real victim of our case here, Celestina: “¿No miras que la ley tiene de ser igual a todos?” (Rojas 259). In the face of the law, all people are equal.

However, what sounds like the triumph of the modern legal system turns out to be the young nobleman's manipulation of the judge. Calisto's further reflections contradict his earlier observation that justice should be immune to personal ties such as friendship and loyalty (" $¿$ No ves que por ejecutar la justicia no había de mirar amistad ni deudo ni crianza?”). Indeed, his conclusion namely, that the judge executed the two servants without a trial in an obvious ploy to cover up Calisto's own transgressions - clearly challenges his own line of argument. After these self-exonerating ponderings, Calisto lapses back into the passion of mad love, culminating in a prolepsis of his own death: "Quiérolo conocer, no quiero con enojo perder mi seso, porque perdido no caiga de tan alta posesión" (Rojas 281). 
Such rhetorical sophistications raise the question of what might be the purpose of adding this contradictory sermon to the articulations of an otherwise very dull protagonist. I will try to address this issue in two ways: first, by examining the semantic tension that arises in Calisto's casuistical argumentation, and second, by looking at the material evidence of the Celestina's historical records.

If we trace the development of Calisto in this passage, we initially perceive an unsettled, almost self-scrutinizing character. All of a sudden, he is aware of his social environment and the effects of his own deeds. Yet in his effort to cope with all this, he gradually regains his self-centered, lofty attitude - only to finally relapse to his state of mad love. This indicates a clear misuse of libre albedrio, which is all the more reprehensible in a character who obviously has the education and the discretionary powers to know better - as his reflections on the circumstances of the crime prove. Therefore, one reason for inserting this passage in the plot development from comedia to tragicomedia is its function as a mise en abyme, or even a metalepsis: Calisto's considerations of the deaths that so far have occurred represent an obliquely ironic, casuistical reconstruction of an action - thereby adumbrating the circumstances of his own death.

With his shift from "I" to "you" in denominating himself, Calisto's discourse invites readers to render him the object of casuistical scrutiny. Our hero thus identifies himself as the ultimate sinner in moral terms; as has been shown, in the light of Tostado's Confessional and the Libro sinodal, his list of lapses includes excessive soberbia.

Furthermore, he performs blasphemy by ascribing divine qualities to his beloved: "¿Yo? Melibeo só y a Melibea adoro y en Melibea creo y a Melibea amo" (Rojas 34), which is his confessional statement in the second auto. Throughout his courtship, Calisto adores her in terms evoking idolatry (Tostado47). Relying on the assistance of a procuress is another infringement of the First Commandment, as we read in the Libro sindical when it instructs confessors to ask their penitents: "[...] si fizo esperimientos o conjurarmento o otras cosas por aver mugeres o otras cosas [...] o fue a devinos o a devinas a tomar consejo con ellas [...]" (Gonzalo de Alba 217). Calisto's denunciation of the judge represents an offense against the Eighth Commandment (Tostado 56 ), and his sexual intercourse with Melibea constitutes one of the worst forms of adultery, estupro (cp. Gonzalo de Alba 216, Tostado 11), since he has corrupted a virgin: "onde en la Eglesia el primero lugar tienen las virgenes [...]," as Gonzalo de Alba specifies (274). Leaving all serious and minor failures aside, his list of 
sins is topped by the repetition of his illicit sexual act, which is a double transgression: Calisto not only penetrates Melibea but also her father's property, as the deed is performed in Pleberio's garden. Such an environment is a quite significant location for the hexameral "ubi" since it corroborates the setting of sin just as it metonymically represents fall, or the original sin.

Most evident in our passage is the role accrued to soberbia: Calisto conceives himself as standing above any jurisdiction. This can be seen in references to his noble descent, which he seems to link to a God-given order; in fact, he invokes a medieval hierarchy where some men are more equal than others. This reveals another semantic layer of the passage. As mentioned, the monologue creates a tension of conflicting legal systems - or in a larger context, of conflicting social systems.

Calisto clearly represents - and reclaims - a social model that in the urban context of the Celestina had become obsolete: he is unproductive, irresponsible, cowardly, and therefore a mere caricature of the medieval courtly lover (Lacarra 2001: 86).

\section{Over Her Dead Body}

These unflattering qualities are paradoxically highlighted by Melibea's praise for her dead lover in the monologue preceding her own suicide. In view of casuistry her final words are also highly questionable. Obviously, she is at least an accomplice in almost every sin of Calisto. But she is not just a passive sinner: her rationalizing strategies for downplaying her own guilt additionally depict her as a countermodel of the ideal penitent. After mentioning abominable figures of classical history such as Nero, she concludes: "Éstos son dignos de culpa, éstos son verdaderos parricidas, que no yo [...]" (Rojas 331).

One could argue that her speech does not allow for casuistical analysis because it does not follow the scheme of the hexameter. Yet, she twice uses confessional formulas: "Tú, Señor, que de mi habla eres testigo [...]" (331) and "Dios quede contigo y con ella. A él ofresco mi alma. Pon tú en cobro este cuerpo que allá baja" (335), as she addresses her father before plunging from her lofty tower. This metaphorical and discursive role reversal between father and daughter amounts to another violation of Christian norms: honor your father and mother, that is, the Fourth Commandment. A further critical point in Melibea's confession is her explicit description of their act of luxuria: "Quebrantó con escalas las paredes de tu huerto, quebrantó mi propositio. Perdí mi virginidad, del cual deleitoso yerro de amor gozamos cuasi un mes" (333). Notably, this graphic clause is another of the tragicomedia's interpolations. 
The passage not only corroborates the severity of Melibea's sin by emphasizing repetition, but its sensual vocabulary also denotes shamelessness. Similarly, Tostado's Confessional and the Libro sinodal both warn repeatedly of detailed descriptions of sexual intercourse because an audience might be seduced by it (Gonzalo de Alba 216). Furthermore, the corporal senses are the gateways for sins, and thus should not inform language (Tostado 58; Gonzalo de Alba 220).

Melibea's inclination toward worldly pleasure is obvious throughout the plot. Her first initiative of inviting the lovesick Calisto to a nocturnal conversation at her gate already constitutes quite an active transgression for an inexperienced maiden. Further evidence of her frivolous character is provided by the two young sex workers Areúsa and Elicia, who, envious of Melibea, sardonically describe her beauty-enhancement measures, such as expensive clothes and makeup (Rojas 206-207). What today might be considered a desirable social imperative was undoubtedly a sinful and pernicious behavior in the eyes of church authorities. Tostado even discusses "[...] colores y trajes/o tajos de ropas en diversos apostamientos de oro o de plata [...]" in a separate chapter of almost three pages, explaining their damaging effect of inducing lujuria (Tostado 14 v. sig.).

And in terms of ecclesiastical norms, Melibea's gravest sin clearly is suicide. In the early modern period, suicide entailed not only loss of honor but also sanctions for the family (cf. Lacarra 2007). Nevertheless, in what is perhaps a daring interpretation of Roman family law, her deed could be regarded as a restoration of her father's honor. This can be demonstrated by comparing her to a literary and historical role model who took her own life as an act of chastity: Lucretia, one of the famous exemplary female life histories in Giovanni Boccaccio's Claris mulieribus. Lucretia suffers rape without resisting in order to save the honor of her husband, since the violator Sextus Tarquinius threatened to kill her together with a male slave and to accuse the two of adultery. Immediately afterwards Lucretia commits suicide to re-establish her husband's reputation. "[T] he Lucretia story aims to create a conscience that makes a woman consider herself unworthy of living once her pudicitia is infringed," notes Nikolaus Benke in explaining the significance of Lucretia's fame within the system of classical patria potestas in Roman law (Benke 290). But some church fathers downplayed this famous female sacrifice in an almost casuistical way:

San Agustín, a diferencia de san Jerónimo y de otros padres de la Iglesia, no admite excepciones, ni en el caso de Lucrecia ni en el de las doncellas que se suicidan para proteger su virginidad.

LACARRA 2OO2: 176 
The well-known narrative substantiates Melibea's trespass, who clarifies that everything happened out of free will: "Todo se ha hecho a mi voluntad" (Rojas 329). Her insistence on following her own conscience points to what later will be known as probabilism. The fact that the servant accompanying Melibea in her last actions is actually named Lucrecia emphasizes an ironic misrepresentation of "acceptable" female suicide.

Following Christian doctrine, both Melibea's and her lover's souls will go to hell since they received neither absolution via confession nor even extreme unction. This could be one of the reasons why her father's closing speech is not a dialogue with God. Far from being a prayer, his lament conspicuously switches addressees, too: after speaking directly to his dead daughter, the father makes accusations against two rather pagan deities complaining that Fortune took his offspring from him even though this should not come under her sphere of operations, since the loss is not a worldly material good:

¿Por qué no destruiste mi patrimonio? [...] Dejárasme aquella florida planta en quién tú poder no tenías. Diérasme, fortuna fluctuosa, triste la mocedad con vejez alegre; no pervertieras la orden.

ROJAS 339

This complaint against a rupture of the generational succession is very important within a narrative obsessed with chronological data - something quite remarkable for the period. And indeed, the question of old and new orders marks the text's semantics on different levels. In Pleberio's monologue, the clash of old and new values entails a very disturbing condensed metaphorization - a metaphorization that, according to my knowledge, has not received its due attention in literary scholarship. After complaining of Fortune's vagaries, Melibea's father repeats a leitmotif of the text: "inicua es la ley que a todos igual no es" (344). Ostensibly echoing Calisto's reproach of justice, Pleberio's accusation is directed at the unfair rules of equivocal Amor's ruthless games: "Dios te llamaron otros, no sé con qué error de su sentido traídos. Cata que Dios mata los que crió; tú matas los que te siguen [...] Ciego te pintan, pobre y mozo" (345).

5 For a deeper analysis of tropes of blindness and of the authorship of the Celestina see Bidwell-Steiner 2021. 
Indeed, the iconographical form of a blind young Cupid enjoyed myriad depictions in what the art historian Erwin Panofsky has classified as "moralizing mythography" (Panofsky 104). He contextualizes the beginning of this pictorial attribute through the two conflicting Christian concepts of amor: caritas and cupiditas. After a short reconciliation in medieval courtly love, this antithesis reappears in the 14th century, where it represents unruly love in the form of a young blindfolded boy (this unknown in classical models) holding an arrow and torch (Panofsky 110 sig.). Thus, the author(s) of the Celestina revert(s) to an already well-established motif.

More startling in the context of the above passage from the Celestina, however, is Panofsky's further explanation of iconographical blindness: "Blind Cupid started his career in rather terrifying company: he belonged to Night, Synagogue, Infidelity, Death and Fortune who had also joined the group of blindfold personifications" (112). This list of appalling blind personae demonstrates unambiguously that in medieval art, blindness was the utmost negative representation of misbelief and annihilation. And some of the undesirable "companions" cited by Panofsky are present in our text: as we have seen, Pleberio starts out with a complaint against Fortune, following his daughter Melibea' suicide before daybreak; thus, Amor, Death, Fortune, Night and arguably Infidelity between daughter and parents are conflated in the motif of blindness.

But what about Synagogue? Like many other scholars, I consider Pleberio to be a converso, as suggested by the tension between his commercial activity and prosperity with his otherwise restrained and pessimistic character. This general observation is borne out by the discourse of the passage in question, as it alludes to a more prominent grief-stricken text: Pleberio's monologue can be related to the "Book of Lamentations" of the Hebrew bible, traditionally ascribed to Jeremiah. This poem is one of five parts of the Ketuvim ("Writings") and mourns the destruction of the city and the temple of Jerusalem. In Rabbinical tradition, Jerusalem is often metaphorized through Abraham's wife Sara in opposition to Hagar, her female slave. The two female figures become prominent allegories in Augustine's City of God - one representing the virtuous, the spiritual, in short, the City of Grace; the other the vicious, the carnal, the City of Natural Law (Augustine: Book 15, 2). Augustine tried to reconcile the vetus testamentum velatum with the novum testamentum revelatum by claiming the presence of the spiritual element of grace within the natural, thereby allowing Jews to participate in Christian communities, albeit in a subordinate 
position. Sara's antipode Hagar was later adopted for Christian propaganda to prevail over Jews; there, Ecclesia embodies the positive traits of Sara, whereas Synagoga refers to Hagar as an image for Judaism persisting in old Mosaic law, blind to Truth (Rove). Panofsky describes Hagar's original iconographical traits such as a broken crown, and her metamorphosis toward the blind representations of Death and Night, which "replaced the figure merely 'plunging into darkness' by a blindfold one" (Panofsky 111). Could it be possible that loveblind Melibea, leaping to her death at the crack of dawn, is a variant of blind Synagogue?

But medieval legal practice offers an alternative explanation for the prominence of this motif with regard to the ascertaining of judicial truth: Ecclesia and Synagoga embody the innocent and guilty parties in court, which often is hold right in front of the church below their personifications (Weis 65-80). This brings us to another, less terrifying personification of blind(folded)ness in Western tradition, which Pleberio also insinuates: Justice. Although Panofsky dismisses any anachronistic parallelization (the attribute of blindness for Justice becomes prominent only in the later 16th century), I cannot believe that the reappearance of equality before the law, a leitmotif of the Celestina, can be a coincidence within this specific context.

The origin of the motif of blind Justicia seems to be Sebastian Brant's Narrenschiff, published in Basel in 1494 (see Möller 111, Panofsky 110, Prosperi 36). Due to the scant dissemination of this culturally peripherical German text in Renaissance Italy, Panofsky questions the impact of its iconographical program. Adriano Prosperi further explores the semantics of Brant's blind justice both from the viewpoint of legal practices and of earlier iconographic traditions of blindness. Seemingly, Brant was a reformer who tried to overcome concurrent legal traditions in order to establish an upright, effective national jurisdiction; he was obviously well acquainted with the target of his mockery, being a trained jurist himself. Brant combined this professional background with a "radical but profoundly religious spirit, sought to point out the failure of every good rule in a human society which by now for him resembled a boatload of fools headed for shipwreck" (6o).

Two elements are conspicuous within Brant's iconography: allegories of blindness often are personifications of a negative principle, and Synagogue is the most prominent female representation of blindness. Reconstructing what I have called condensed metaphorization serves to elucidate unsettled discrepancies in the iconography of blind Justice: "The rapid success of the figure of the blindfolded goddess was influenced by familiarity with the image of the

6 Interestingly, early modern Sephardic Kabbalah seemed to have re-appropriated the allegorical Christian Ecclesia for Shekhinah, i.e. divine wisdom, as Tzahi Weiss suggested. 
Christ of the Passion" where "Justice took the place of the mocked Just One" (Prosperi 64). In this view, the mourning human Christ is an incarnation of true faith as he faces the scorning Pharisees, and thus is a precondition for the triumph of Ecclesia. In a process of parallelization, the already familiar allegory of Justice as a young maiden suddenly appears blindfolded - reminiscent of the suffering Jesus - so as to avoid being corrupted by material impressions. Blindness becomes a positive, active trait, whereas in the examples mentioned earlier it represents a passive state of ignorance. In this view, pictorial and verbal depictions of blindness and foolishness, as in the Narrenschiff, function as a paradoxical intervention for reforming juridical and ecclesial conventions.

Like this northern example, the Celestina also blends mockery and moralism stemming from a juridical culture. But are we facing only a phenomenon of mere coincidence, a sign of contemporaneity? Without being able to present conclusive proof, I would like to convey some "presumptive evidence" for a deeper intertextual interdependence between the texts/authors. First of all, the very last words of Pleberio, concluding the Celestina, are also the last addition from the reshaping process into the tragicomedia: “¿Por qué me dejaste triste y solo in hac lachrimarum valle?" (Rojas 347). This is highly reminiscent of the Man of Tears, the Christ of the Passion, as visualized in the above-mentioned tradition. In this reading, Pleberio appears to be a figure of liminality, having irrevocably lost his former faith and been suspended from grace. Interestingly, the "concluye el autor ..." of the tragicomedia explicitly relates the message of the overall text to Luke's narration of Christ's passion: "Amemos a Aquel que espinas y lanza,/azotes y clavos su sangre vertieron./Los falsos judíos su haz escupieron,/vinagre con hiel fue su potación" (Rojas 349).

Apart from this textual marker of an intertextual relationship between the Celestina and the Narrenschiff, it is worth noting that the inventory of the National Library in Madrid lists several versions of the Latin translation of the Narrenschiff, Stultifera Navis (1497) by Jakob Locher, and the juridical writings of Sebastian Brant. Given the juridical background of the Celestina's author(s), it seems highly probable that they were acquainted with this quite important northern colleague. Furthermore, the Madrid library houses the only Spanish edition of one of the most prominent supplements of the Narrenschiffs Latin version, the Stultiferae Naves (1500) by Jodocus Badius Ascensius. It was even released by the same publisher who issued the oldest surviving version of the Celestina (1499), also editing the Confessional del Tostado in Burgos that same year: Fadrique Biel ("de Basilea"). ${ }^{7}$

7 The version of the Biblioteca nacional de Madrid obviously was bound together with an edition from Lyon. For my argument Badius Ascensius' own activity between Lyon and Basel and Friedrich Biel's training in Basel gives further evidence (Bidwell-Steiner 2021). 
The idea that everyone is equal before the law runs as a recurring chorus through the entire text: three main characters - Celestina, Calisto and Pleberio - express it in crucial moments, emphatically mirroring the efforts of an emerging urban bourgeoisie as it attempts to supersede traditional hierarchies. At the threshold between medieval and early modern Spain we observe pogroms, riots, and a struggle for hegemony within the Spanish aristocracy. Royal efforts towards a national organization of the Peninsula were constantly threatened by tensions within its provinces. What under the reign of Carlos I would lead to the Guerra de la comunidades de Castilla (1520-22) already had its heralds at the end of the 15 th century when aspiring urban elites became independent from the traditional aristocracy; in this battle, the University of Salamanca was a breeding ground for humanistic reforms with Tostado, Fernando de Roa and Antonio Nebrija as key figures.

This brings me to historical evidence for interpreting casuistical argumentation in the text (cf. Castillo Vegas). In José Luis Canet Vallés' elaborations (2008) on the fascinating editorial history of La Celestina, we learn that around 1500, the text was simultaneously published in different versions, making it one of the most widely distributed Spanish literary texts of its epoch. Although most scholars assume an editio princeps from Salamanca, ${ }^{8}$ hermeneutic efforts are constrained by the fact that both versions - the comedia of 16 acts and the tragicomedia of 21 acts - were in simultaneous circulation. Only university textbooks had a reach similar to that of the Celestina. Recognizing the fact that printers and editors involved in the different editions of the Celestina also issued academic publications, Canet Vallés links the Celestina to a university circle. In fact, the inclusion of Calisto's casuistical ponderings helps us to identify the diez personas intended in the introductory quote. Fernando the Rojas, the nominee of the acrostic and commonly held to be the author of the entire text (aside from its first act), studied law in Salamanca and was thus familiar with casuistical discourse. Nevertheless, Canet Vallés (2017: 35 sig.) doubts Rojas' single authorship - because of the enormous costs of such a publishing enterprise, and also judging from its immediate success. He proposes a far more prominent affiliation.

State-Decreed Humanism?

A crucial figure in the struggle for hegemony over the Iberian Peninsula was Cardinal Cisneros, the confessor of Queen Isabel. A son of humble hidalgos, he

8 One evidence for such a claim is the afterword of Alonso de Proaza, the "corrector" of the text, which refers to the publication year 1500 and Salamanca. 
became one of the most influential statesmen of the Renaissance and a fervent religious reformer. One of his stepping stones on the way to power was the founding of the University of Alcalá, accompanied by a sort of state-mandated humanism including projects such as the Complutensian Polyglot Bible. Canet Vallés suggests that his spirit of reform, together with his financial power, make Cardinal Cisneros a possible candidate for the spiritus rector of the Celestina, in collaboration with his friend Alonso de Proaza (who appears to be the corrector of the Valencia edition, Canet 2017: 40).

As I have tried to show with the unusual conflation of blind representations and parallels to the Northern literary text, this suggestion bears some plausibility. Indeed, a reconsideration of aequitas, or equality, was at the core of legal debates at the threshold to modernity. Late medieval canonists combined the Roman roots of this legal principle with casuistical approaches from the Aristotelian Nicomachean Ethics (re-discovered in 1245) and the Augustinian principle of mercy. In doing so, they aimed to establish a harmony between forensic and moral standards (Johnson/Toulmin 116). The realization of such intellectual endeavours doubtlessly converged with the reformatory efforts of the statesman and the churchman Cisneros.

But how do we explain the hilarious and erotic parts of the text? Should we just "take example," as the paratext (Rojas 13) advises us, and relapse into a medieval understanding of literature as exemplum? I do not think so. As I have tried to show, the tensions between and within the three monologues of the Celestina point to different world views: Calisto is a representative of the aristocracy, which will soon oppose the urban elites who bolster the power of the Catholic Monarchs. Yet, his egregious speech during sexual intercourse depicts him as more like a student who neglects courtly manners, and features the misogyny of collegiate audiences. In contrast, Calisto's (male) counterpart Pleberio could be assessed as a progressive, meritocratic urban entrepreneur; yet the text's closing passage demolishes his value system. And Melibea might pass as an allegory of Synagoga (with contemporaneous allusions to heresy) or as a late penitent executive of the "law of the Father." Then, however, her sophisticated claim of personal freedom would read as a proto-feminist statement. A similarly polymorphous personality can be attributed to other female figures of the text, namely to Celestina and Areúsa. ${ }^{10}$

Therefore, the readers have to make up their mind about the semantic excess, which is a product of a creative competition in casuistical eventualities

9 The notion is borrowed from Jacques Lacan's analysis of patriarchal societies.

10 For an interpretation of the female personae of the text see Bidwell-Steiner 2015 . 
within the genre of quodlibet. ${ }^{11}$ On one level, we can almost picture a group of academics inventing a tricky case story in the forensic debate culture of the so-called "ius controversum," where "finge" (latin for invent) is imperative for creating a legal fiction in order to test one's ability as a lawyer (Benke 2000: 12). Not insignificantly, these argumentative tensions reflect a climax in the humanistic tradition of the University of Salamanca in a moment when the sovereigns betrayed their urban allies in their efforts to introduce a more secular - and equal - order (cf. Castillo Vegas 2004). Before Cisneros could inaugurate his "own" university, he allegedly tried to take the reins of the one in Salamanca. This training post for future lawyers was the domain of another important counselor of the Queen, Antonio Nebrija. The Italian-trained humanist shared Cisneros' hermeneutic concerns. But he favored a more heterodox version of philological scrutiny in the vein of Lorenzo Valla's linguistic philosophy, which even caused him troubles with the Inquisition. In his Diccionario de derecho civil, Nebrija elaborated on the legal enigma, defining it as a paradox (Goodrich 85). Such ponderings on juridical riddles might well have been developed as a playful classroom endeavor, eventually plotting a comedia based on different theoretical and imaginary sources.

Seen in this way, Calisto's paradoxical monologue traces the juristic theory and practice from which the text originated, with inconsistencies between different approaches playfully performed in the fictional text. In a broader sense, it also reflects the different world views represented by the eminent Renaissance scholar Antonio de Nebrija and the powerful conservative statesman Cardinal Cisneros.

And this is precisely the reason why the Celestina is so important for the mutual history of the novel and of moralism. What emerges here is a specific tension between different casuistical options. The relationship between casuistry and imaginative literature is a history of increasing narrative complexity. On the one hand, this relationship sheds light on remote ludic and rhetorical cultures. On the other, it helps to reveal social tensions and shifting power relations. Considering that the heyday of moralism in Spain is only to come 150 years after the publication of the Celestina, the importance of fictional literature for molding society and its institutions cannot be underestimated. Firstly, the Celestina already presents a catalogue of circumstances like those to be found in the later School of Salamanca; secondly, it also contains an

11 The term refers to a well-known practice in medieval universities ("disputatio de quodlibet"): a candidate had to elaborate on a certain subject or case without preparation, which often generated quite funny effects. In this context, see also Anita Traninger's contribution in this volume. 
illustration of judicial practice. These twofold semantic vectors extend beyond any model of humanistic comedy and of reprobatio amoris. The interpolations of the tragicomedia consist mainly in the protagonists' reflections on the circumstances of their actions, which gives the characters a depth and liveliness not always found in the comedia. If we acknowledge the narratological basis of such a solid field as jurisprudence, we might also restore the (admittedly problematic) term "fiction" to literary studies. For the overall subject of this volume, it is important to identify the benefit of this casuistical fastidiousness: it breathes life into the simple, one-dimensional figures of exempla. This new depth is best demonstrated through Calisto. Inertly lovelorn, he starts out as one of the most boring figures in the text; but the juridical refinement of his character paves the way for narrative complexity. In narratological terms, this abject sinner is the antihero, a figure later to become an eminently attractive protagonist in European literature. The rise of the picaresque genre is an important step in this direction, as the following essays recount.

\section{Works Cited}

Anon. Celestina comentada. Eds. Luise Fothergill-Payne, Enrique Fernández Rivera and Peter Fothergill-Payne. Salamanca: Ediciones Universidad 2002.

Baranda, Consolación. "Cambio social en La Celestina y las ideas jurídico-políticas en la Universidad de Salamanca." El Mundo social y cultural de la Celestina. Actas del congreso internacional, Universidad de Navarra, junio, 20or. Eds. Ignacio Arellano and Jesús M. Usunáriz. Madrid: Iberoamericana/Vervuert, 2003: 9-25.

Bataillon, Marcel. Erasmo y España. Estudios sobre la historia espiritual del siglo XVI. México-Madrid-Buenos Aires: Fondo de Cultura Económica, 1966.

Bataillon, Marcel. La Célestine selon Fernando de Rojas. Paris: Marcel Didier, 1961.

Bechtel, Florentine. "Alonso Tostado." The Catholic Encyclopedia 14 (1912). Ed. Robert Appleton Company New York. 21 Oct. 2020: <http://www.newadvent.org/ cathen $/ 14788 \mathrm{~b}$.htm $>$.

Benke, Nikolaus. "In sola prudentium interpretatione. Zu Methodik und Methodologie römischer Juristen." Norm und Entscheidung. Prolegomena zu einer Theorie des Falls. Ed. Birgit Feldner and Nikolaus Forgó. Wien/New York: Springer, 200o: 1-86.

Benke, Nikolaus. "On the Roman father's right to kill his adulterous daughter." The History of the family 17.3 (2012): 284-308.

Bidwell-Steiner, Marlen. "Sex Acts in the Celestina: An Ars Combinatoria of Desire." Sex Acts in the Early Modern World. Eds. Amyrose McCue Gill and Vanessa McCarthy, Renaissance and Reformation 38.4 (2015): 121-144. 
Bidwell-Steiner, Marlen. "Law New and Old: Tropes of Blindness in the Celestina." Celestinesca 45 (2021).

Canet Vallés, José Luis. "La Celestina en la 'contienda' intelectual y universitaria de principios del siglo XVI." Celestinesca 32 (2008): 85-108.

Canet Vallés, José Luis. "The Early Editions and the Authorship of Celestina." $A$ Companion to Celestina. The Renaissance Society of America Texts and Studies 9. Ed. Enrique Fernandez. Leiden: Brill, 2017: 21-41.

Castillo Vegas, Jesús Luis. "Aristotelismo político en la Universidad de Salamanca del siglo XV: Alfonso de Madrigal y Fernando de Roa." La corónica: A Journal of Medieval Hispanic Languages, Literatures, and Cultures 33.1 (2004): 39-52.

Faulhaber Charles, B. "Celestina de Palacio." Celestinesca 14.2 (1990): 3-40.

Faulhaber Charles, B. “Celestina de Palacio: Rojas's holograph manuscript?” Celestinesca 15.1 (1991): 3-51.

Gómez Moreno, Ángel. "La torre de Pleberio y la ciudad de La Celestina (un mosaico de intertextualidades artístico-literarias ... y algo más)." El Mundo socialy cultural de la Celestina. Actas del congreso internacional, Universidad de Navarra, junio, 2001. Eds. Ignacio Arellano and Jesús M. Usunáriz Madrid: Iberoamericana/Vervuert, 2003: 211-236.

Gonzalo de Alba. "Libro sinodal." (1410). Synodicon Hispanum. Cuidad Rodrigo, Salamanca y Zamora IV. Eds. Antonio Garcia y Garcia et al. Salamanca: Biblioteca de Autores cristianos, 1987: 48-293.

Goodrich, Peter. "Legal Enigmas - Antonio de Nebrija, The Da Vinci Code and the Emendation of Law." Oxford Journal of Legal Studies 30.1 (2010): 71-99.

Guiance, Ariel. "Iglesia e ideología de la violencia en la Castilla medieval. Crímenes e infanticidios en la legislación canónica." Mediaevistik 12 (1999): 209-227.

Iglesias, Yolanda. "Implicaciones legales de las seis muertes en La Celestina: Un acercamiento histórico-literario." Romance Quarterly 62.2 (2015): 59-70.

Infantes, Victor. "Los libros 'traydos y viejos y algunos rotos' que tuvo el Bachiller Fernando de Rojas, nombrado autor de la obra llamada Celestina." Bulletin Hispanique 100.1 (1998): 7-51.

Jonsen, Albert R./Toulmin, Stephen. The Abuse of Casuistry. A History of Moral Reasoning. Berkeley/Los Angeles/London: California University Press, 1988.

Justo Fernández, Jaime. "Los libros en los sínodos medievales de la península ibérica." Revista Española de Derecho Canónico 71.176 (2014): 165-207.

Kallendorf, Hilaire. Conscience on Stage. The Comedia as Casuistry in Early Modern Spain. Toronto: University Press, 2007.

Lacarra Lanz, Eukene. "La muerte irredenta de Melibea." Proceedings of the International Symposium 1502-2002: Five Hundred Years of Fernando de Rojas' "Tragicomedia de Calisto y Melibea" (18-19 October 2002, Department of Spanish and Portuguese, 
Indiana University, Bloomington). Ed. and introd. Juan Carlos Conde. New York: Hispanic Seminary of Medieval Studies, 2007: 173-208.

Lacarra Lanz, Eukene. "Los Amores citadinos de Calisto y Melibea." Celestinesca 25.1-2 (2001): 83-100.

Möller, Ernst von. "Die Augenbinde der Justitia." Zeitschrift für christliche Kunst. XVIII. 4. (Düsseldorf 1905): coll. 107-122, 141-152.

O'Banion, Patrick J. “'A Priest who Appears Good': Manuals of Confession and the Construction of Clerical Identity in Early Modern Spain." Nederlands archif voor kerkgeschiedenis/Dutch Review of Church History 85 (2005): 333-348.

Panofsky, Erwin. Studies in Iconology: Humanistic Themes in the Art of the Renaissance. Chicago: University Press, 1982.

Paolini, Devid. "Un manuscrito desconocido del 'Tratado de cómo al hombre es necesario amar' (Ms.18665 de la BNE)." eHumanista 11 (2008): 65-8o.

Prosperi, Adriano. Justice Blindfolded: The Historical Course of an Image. Leiden: Brill, 2018.

Rojas, Fernando de. La Celestina. Tragicomedia de Calisto y Melibea. Eds. Francisco J. Lobera, Guillermo Serés, Paloma Díaz-Mas, Carlos Mota, Iñigo Ruiz Arzalluz and Francisco Rico. Madrid: Real Academia Española, 2011.

Rove, Nina. The Jew, the Cathedral and the Medieval City: Synagoga and Ecclesia in the Thirteenth Century. Cambridge, UK: University Press, 2011.

Ruiz-Capillas, Jusdado. "Ius Commune y Common Law." Cuadernos de Historia del Derecho 15 (2008): 327-344.

Sánchez Herrero, José. "La Literatura catequética en la Península Ibérica 1236-1553." En la Espana medieval 5. Madrid: Editorial de la Universidad Complutense, 1986: 1051-1118.

Saquero Súarez-Somonte, Pilar/González Rolán, Tomás. "Las Questiones sobre los dioses de los gentiles del Tostado: un documento importante sobre la presencia de Boccaccio en la literatura medieval española." Cuadernos de Filología Clásica XIX (1985): 85-114.

Serés, Guillermo. “La obra y los autores della 'comedia' a la 'tragicomedia.'” La Celestina, 2011: 361-401.

Soto Rábanos, José María. "Visión y tratamiento del pecado en los manuales de confesión de la baja edad media hispana." Hispania Sacra 118 (2006): 411-447.

Tostado (Alfonso Fernández de Madrigal). Confessional. Valladolid: Diego Gumiel $15 \circ 3$. Weis, Adolf. “Die 'Synagoga' am Münster zu Strassburg.” Das Münster 1 (1947): 65-8o.

Weiss, Tzahi. "Who Is a Beautiful Maiden without Eyes? The Metamorphosis of a Zohar Midrashic Image from a Christian Allegory to a Kabbalistic Metaphor." The Journal of Religion 93.1 (2013): 6o-76. 